Abstract
It is sometimes claimed that an increase in aid might cause Dutch Disease-that is,
an appreciation of the real exchange rate which can slow the growth of a country's
exports - and that aid increases might thereby harm a country's long-term growth
prospects. This essay argues that it is unlikely that a long-term, sustained and
predictable increase in aid would, through the impact on the real exchange rate, do
more harm than good, for three reasons. First, there is not necessarily an adverse
impact on exports from Dutch Disease, and any impact on economic growth may be
small. Second, aid spent in part on improving the supply side-investments in
infrastructure, education, government institutions and health-result in productivity
benefits for the whole economy, which can offset any loss of competitiveness from
the Dutch Disease effect. Third, the welfare of a nation's citizens depends on their
consumption and investment, not just output. Even on pessimistic assumptions, the
additional consumption and investment which the aid finances is larger than any
likely adverse impact on output. However, the macroeconomic effects of aid can
cause substantial harm if the aid is not sustained until its benefits are realized. The
costs of a temporary loss of competitiveness might well exceed the benefits of the
short-term increase in aid. To avoid doing harm, aid should be sustained and
predictable, and used in part to promote economic growth. This maximizes the
chances that the long-term productivity and growth benefits will offset the adverse
effects-which may be small if they exist at all—-that big aid surges may pose as a
result of Dutch Disease.

The Center for Global Development is an independent think tank that works to reduce global poverty and inequality through rigorous research and active engagement with the policy community.

Use and dissemination of this Working Paper is encouraged, however reproduced copies may not be used for commercial purposes. Further usage is permitted under the terms of the Creative Commons License. The views expressed in this paper are those of the author and should not be attributed to the directors or funders of the Center for Global Development.

www.cgdev.org 


\title{
A Policymakers' Guide to Dutch Disease
}

What is Dutch Disease, and is it a problem?

\author{
Owen Barder \\ Center for Global Development \\ July 2006
}

Thanks to Chris Adam, William Cline, David Goldsborough, Robert Powell, Steve Radelet, David Roodman, Tony Venables and Adrian Wood for comments on earlier versions of this paper. All errors are my own. 


\section{A very busy policy-maker's guide to the Dutch Disease}

* A big increase in aid could lead to a reduction in a country's exports. This is called "Dutch Disease". The paper explains how this could happen.

* There is a mountain of evidence that countries benefit from global integration and more trade. If a country wants higher economic growth and faster reduction of poverty then it should aim for more trade, not less. If aid causes Dutch Disease, and if that means lower exports, this might in turn harm a country's long term economic performance.

* Despite these concerns, it is very unlikely that a long term, sustained and predictable increase in aid would, through the impact on the real exchange rate, do more harm than good. There are three reasons for this.

* First, there is not necessarily a significant negative impact on exports from Dutch Disease, and the adverse impact on economic growth may be small.

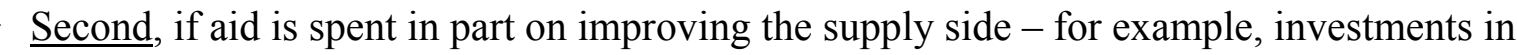
infrastructure, education, government institutions and health - then there will be productivity benefits for the whole economy. These could offset any loss of competitiveness from the Dutch Disease effect.

* Third, the welfare of the nation's citizens is the product of their consumption and investment, not just the nation's output. Even on pessimistic assumptions, the value of additional consumption and investment which the aid finances is larger than any likely adverse impact on output.

However, these macroeconomic effects of aid could cause substantial harm if aid is not sustained until the benefits of the aid are realized. The costs of a temporary loss of competitiveness might well exceed the benefits of the short-term increase in aid.

* To avoid doing harm, aid should be sustained and predictable. This maximizes the chances that the long term productivity benefits and growth benefits will offset any the threat of adverse effects which may be small if they exist at all - that big aid surges may pose as a result of Dutch Disease. 


\section{What is Dutch Disease?}

Economists use the term "Dutch disease" to describe a reduction in a country's export performance as a result of an appreciation of the exchange rate after a natural resource such as oil has been discovered.

\section{Why is it called Dutch Disease?}

"The Dutch Disease" was the title of an article in The Economist in 1977 about the impact on the economy of The Netherlands of the discovery of natural gas in the North Sea. ${ }^{1}$ The large foreign exchange earnings from the export of the gas led to a shift in prices and in the exchange rate, so that previously competitive exporters lost market share, and production of those exports fell.

\section{How does aid cause Dutch Disease?}

Aid is a generally a transfer of foreign currency. ${ }^{2}$ This helps the recipient country by enabling it to import goods and services without having to produce and sell exports to pay for them. ${ }^{3}$

Because aid is a gift of foreign currency, for it to have any benefit for the recipient country, some combination of the following three things must happen:

a. shift of production from exports

exports can be reduced while imports stay the same; this frees up productive resources (especially people) to increase production of additional non-tradables which are then consumed locally;

b. shift of production from import substitutes goods and services can be imported instead of being produced locally; the consumption of these goods is unchanged but they are provided from abroad; this also frees up domestic resources for production of additional non-tradables to be consumed locally;

c. additional imports

additional goods and services can imported; these additional imports add to local consumption and were not affordable without the aid.

The first two of these - a shift of production from exports and from import substitutes, which are together called "tradables" - are together known as "Dutch Disease". It is called a "disease" because domestic production of tradables has been reduced. But in both cases, the aid permits higher consumption of non-tradables than was possible without the aid, by switching productive resources into non-tradables from tradables.

\footnotetext{
1 "The Dutch Disease", The Economist November 26, 1977. pp. 82-83.

${ }^{2}$ This problem, and hence this paper, refers only to resource transfers. There are many other valuable forms of aid - such as knowledge sharing, insurance, investment in global public goods, capacity building - which are not the subject of this note.

3 Technically, aid is said to be absorbed when the current account deficit (excluding aid) increases. Aid only enables an economy to invest and consume more by financing an increase in imports or a reduction in exports. Gupta, Yang \& Powell (2005) discusses the recipient country's choice to use ("absorb") aid or save it.
} 


\section{Could the country save the aid instead?}

In principle, a country could instead save the foreign aid, for example by building up its foreign exchange reserves. This would defer the day when it is used in one of the three ways described above (and would correspondingly defer the benefits); but although it changes the time when the aid is used, it does not enable a country to use aid without eventually increasing imports or reducing exports.

\section{How does it affect exporters if a country spends more on public services?}

Suppose that the government or an NGO uses aid to pay for local training of health care workers. The aid arrives as dollars (which give the owner a right to consume imports), so it has to sell those dollars for local currency (the right to use local resources) which it needs to employ trainers, rent buildings, to pay telephone bills and so on.

Because the government (or whoever is using the aid) wants to employ more workers or rent more land, if there is no excess supply of these resources then the prices of these goods and services rises in response to the higher demand.

Exporters get their revenues in dollars, and they sell at world prices. Their costs (measured in local currency) go up, but their revenues (measured in dollars) do not increase. Export firms become less profitable; and they may grow more slowly, or perhaps contract or even close. Exporters can afford to pay a little less for salaries for their workers, so jobs in export firms become less attractive relative to jobs in non-tradable activities such as teaching or nursing. Furthermore, local companies making products for the home market will find that imports from abroad have become cheaper relative to what they cost to make locally, so these companies may lose market share to imports.

In other words, because the demand for non-tradables has risen, the price of non-tradables goes up relative to the price of tradables. This price rise attracts more firms and more resources (workers, land, etc) into the production of non-tradables rather than tradables.

This direct effect of aid is not bad in itself in the short term The immediate impact of the aid has helped the country by allowing it to import more and by allowing it to switch its productive resources from exports and import substitution into the production of non-tradables, while still being able to enjoy the same level of imports because it can pay for them with additional aid rather than export earnings. The switch only becomes harmful if the contraction in tradable production has adverse effects on the long term growth rate of the country. We will consider that possibility later.

In a market economy, this switch in production occurs by a change in relative prices that encourages more non-tradable production and less tradable production.

\section{What is the real exchange rate?}

The real exchange rate is defined as the price of non-tradable goods and services relative to tradable goods and services. When demand for non-tradables increases, the cost of those goods and services may rise relative to tradables. This is called an appreciation of the real exchange rate.

A country generally experiences an appreciation of its real exchange rate as it industrializes. As productivity, output and incomes increase relative to the rest of the world, the relative price of its non- 
tradables rises relative to tradables. In the case where this occurs without aid, the long-run appreciation of the real exchange rate is driven by a rise in productivity, output and incomes. The appreciated real exchange rate is the corollary of higher levels of incomes and consumption that the country enjoys as productivity increases and its citizens becomes richer.

The appreciation resulting from aid inflows is different: the aid causes an immediate appreciation of the exchange rate before there has been an increase in productivity and output. The aid finances a level of consumption and investment that is higher than the country's economic output would permit. The appreciated real exchange rate is in line with the higher consumption that the country enjoys as a result of the sustained increase aid; but the higher consumption and real exchange rate are both out of line with the nation's underlying productivity and output.

\section{Is the real exchange rate the same as the market exchange rate?}

No. The real exchange rate is a measure of relative prices. It is possible for the domestic price of nontradables to rise (measured in local currency) while the market exchange rate, and hence the price of tradables (measured in local currency), stays the same. This increase in the domestic price level, with no change in the market exchange rate, would be an appreciation of the real exchange rate because relative prices have changed.

\section{How much does tradable production fall in response to aid?}

The increased demand for non-tradables raises domestic prices if supply cannot easily increase to meet the additional demand - for example, because there is a lack of skilled labor. In this case, the rise in domestic prices of non-tradables is needed to attract sufficient productive resources out of tradables into non-tradables, and this causes the fall in tradables production.

The impact of the aid on tradable production therefore depends in part on the extent to which there are unemployed resources in the economy. If there are spare resources, the increased demand for nontradables can be met with no fall in tradable production and no appreciation of the real exchange rate. ${ }^{4}$ But if some factors of production are scarce, their price rises, the real exchange rate appreciates, and tradable production contracts to free up those resources for non-tradables. The size of the initial fall in tradable output depends on a number of characteristics of the economy, including: the share of tradable goods in the additional consumption; the capacity to substitute between domestically-produced and imported goods; the elasticity of supply, and the amount of spare capacity in the economy.

In the longer term - as we shall see below - the effect of the aid also depends on whether it is used to improve the productivity of the economy and to remove supply constraints.

Empirically, the size of this effect is very hard to establish. In general, the most aid-dependent countries have a poorly performing tradable sector. ${ }^{5}$ But it is difficult to establish the cause of this relationship. If donors more often give aid to countries that are poor in part because they have not been successful at developing markets for their exports, then high aid will be correlated with low and slow-growing exports, but in this case aid is not the cause of the low growth of exports. Studies do try to remove this

\footnotetext{
${ }^{4}$ Nkusu (2004) suggests the possibility of unemployed resources has been neglected in some analysis of Dutch Disease.

${ }^{5}$ Bulír and Lane (2003).
} 
effect, but it is statistically very difficult to do, so the estimates of the effect of aid on exports must be treated as suggestive.

One way to calibrate the possible size of the effect is to use economic models. A recent model of Ethiopia suggests that, with no productivity benefits from aid, if aid doubled from $20 \%$ of GDP to $40 \%$ of GDP, exports might fall by $6 \%$ of GDP over ten years. ${ }^{6}$ A more generic model finds that an increase in aid of $2 \%$ of GDP could lead - through these demand effects alone and with no productivity benefits - to a larger initial fall in the real value of exports of $7 \%$ (about $1 \frac{1}{2}$ percent of GDP). ${ }^{7}$

Another way to estimate the size of the effect is to look at the relationship aid on the amount of laborintensive exports. A study by IMF economists looking at data for the 1990s suggest that, again without any benefits from the aid on productivity, an increase in aid of $20 \%$ of GDP might lead to a reduction in exports of the order of $30 \% .^{8}$ In a country in which exports make up a fifth of GDP, this would mean a fall in exports of $6 \%$ of GDP, about the same as predicted in the Ethiopia model.

How big is the effect on the real exchange rate?

By contrast with the effect of aid on exports, economic statisticians have not found a strong relationship between the amount of aid a country receives and its real exchange rate. ${ }^{9}$ One empirical study did find that a doubling of aid might lead to an appreciation of the real exchange rate of $4 \%$ in the short term and up to $30 \%$ over a decade. ${ }^{10}$ But aid to Africa has often been associated with depreciation, not appreciation, of the real exchange rate. ${ }^{11}$

As with the impact on exports, the figures are difficult to disentangle statistically. But if the figures tell us anything, the lack of a strong relationship between high levels of aid and an appreciation of the real exchange rate casts some doubt on the view that high levels of aid are the most significant cause of problems in the export sector. This makes it more likely that the correlation between high aid and slowgrowing exports is because countries with poor export performance tend to get more aid.

What is the short-term impact on total output?

The fall in the production of exports is caused by the market responding to changing composition of demand by shifting productive resources from tradables to non-tradables. This shift reflects the lower need for exports to pay for imports, and the rising demand for non-tradable production. Because tradable output falls so that production can shift to non-tradable production, the immediate effect is an increase in total output in real terms. ${ }^{12}$

\footnotetext{
${ }_{7}^{6}$ Sundberg \& Lofgren (2005). This was a scenario with no benefits to productivity from the aid increases.

${ }^{7}$ Adam and Bevan (2004).

${ }^{8}$ Rajan and Subramanian (2005).

${ }^{9}$ Adenauer \& Vagassky (1998); Adam (2005) pp. 11-12; Gupta, Powell \& Yang (2005) Appendix 1.

${ }^{10}$ Prahti, Sahay \& Tressel (2003).

${ }^{11}$ Nyoni (1998), Sackey (2002), Adam, Bevan \& Chambas (2003).

${ }^{12}$ This is true when measured at the new relative prices between tradable and non-tradables. The value of the bundle could in principle fall measured at the old relative prices.
} 


\section{So does a short-term fall in tradables matter?}

There is an enormous amount of evidence that an expansion of exports (particularly exports of laborintensive manufactures) is generally good for developing countries. ${ }^{13}$ Greater exports lead to more jobs, increased productivity, wages and incomes, and the export sector is a conduit for new technologies and learning. Export-led growth has been the main path out of poverty for millions of people in the last three decades, and the countries that have failed to grow have generally been those that have not managed to spark sustained growth in labor-intensive exports. ${ }^{14}$

Yet exports are not good in themselves - it is not intrinsically to a country's benefit to make something for somebody else to consume. Imports are really what we want: someone else makes them, and we get to consume them. Production for exports is a burden on the economy; worth doing because exports enable the country to pay for imports. In other words, the value of tradable production is that it pays for imports, or substitutes for them. If a country can pay for its imports some other way - for example, by selling gold or receiving aid - then its citizens are better off because they do not have to make so much for export and that means they can keep more of what they make for themselves.

We have seen that the immediate impact of an increase in aid is a one-off change in the composition of output, reducing the amount of resources devoted to production of tradables. But this fall in tradable output is not itself a bad thing for the country in the short term, as the imports that were financed by the sale of this output are now financed by the aid instead. (Though this is to the benefit of the country as a whole, it is clearly a bad thing for people employed in that sector who lose their jobs. We will discuss the distributional effects below.) So in the short run, as a matter of accounting, this is a net gain to the country because (in addition to the extra imports that can be afforded) resources are freed up from the tradable sector which are used instead to produce for domestic consumption.

Given the importance of exports for long-term economic growth, however, if the contraction in the export sector leads to slower long-run growth of the tradable sector then this could jeopardize future opportunities for economic growth, jobs and development. We shall consider below the longer term effects, which include possible adverse effects on economic growth of the contraction of the tradable sector, and the possible beneficial effects of the aid on productivity and growth.

\section{How does the aid increase affect exports in the long run?}

We have seen that the initial impact of the increase in aid is that output switches from tradables to nontradables - which is the Dutch Disease. Furthermore, this direct, short-term impact is not, of itself, harmful. But this is a purely theoretical construct: it is the long-term effects that matter.

There are two possible long-term effects on economic growth resulting from aid and the slower growth of tradable production that may result:

* The effect on growth of smaller tradable production

A successful export sector is a critical driver of economic growth. There are significant long-run benefits from trade which spill over to the economy as a whole; these benefits include the competitive pressure of having to meet the standards of international markets, the transfer of

\footnotetext{
${ }^{13}$ Berg \& Krueger (2003). Thanks to Steve Radelet and Tony Venables for emphasizing this point.

${ }^{14}$ Hausmann, Pritchett and Rodrik (2004).
} 
ideas and technology from abroad, and access to intermediate goods which increase domestic productivity.

* The effect on growth of productivity increases because of aid There are long-term benefit of investments financed by aid - such as in infrastructure, health, education or public administration - which may improve productivity and growth in both the tradable and non-tradable sector.

The overall effect on economic growth of a sustained increase in aid and the corresponding possible contraction in tradables depends on the relative sizes of these two effects.

The aid inflows may have other effects on the recipient economy, for example through transactions costs to the recipient economy or effects on the political economy and accountability of the government. This broader range of issues is addressed in a separate paper. ${ }^{15}$

\section{How big is the impact of a smaller tradable sector on long-run growth?}

Openness to the global economy is an important source of economic benefits: imports of investment and intermediate goods that may not be available domestically, the transfer of ideas and technology, the impact of competition which drives up productivity, export earnings which provide the foreign exchange needed to pay for the imports which support growth, and learning by doing. In the early 1990s, the World Bank emphasized the role of exports of manufactured goods in stimulating growth, advocating exports as a "highly effective way of enhancing absorption of international best practice technology, [and] thus boosting productivity and output growth."

While there is broad agreement that there is a positive association between trade and growth, there is quite a bit of uncertainty about the precise channels through with this operates. We do not know if whether trade leads to economic growth primarily because of higher productivity growth in the export sector, or because of beneficial effects of imports, or both. Usually these go hand-in-hand, because exports are needed to pay for imports; but the distinction matters if foreign aid pays for a higher level of imports.

If the main benefits of openness are the transfer of ideas and technology from foreign rivals, the impact of competition from imports on improving performance in the domestic economy and access to intermediate goods, then the level of imports is an important determinant of productivity and economic growth. This theoretical point is supported by an empirical study which finds that imports, rather than exports, drove productivity growth in Japan and other East Asian countries. ${ }^{17}$ But higher productivity is also driven by increased exports, through greater market engagement - the need to produce high quality goods at competitive prices to sell on world markets. The fact that manufactured exports have a greater impact on economic growth than agricultural exports suggests that some of the effect on growth relates to the effect on productivity in the export sector, and not merely the imports that are financed by the

\footnotetext{
${ }^{15}$ see Barder (2006).

${ }^{16}$ World Bank (1993) The East Asian Miracle.

${ }^{17}$ Lawrence \& Weinstein (1999).
} 
exports. Overall the empirical evidence about the mechanism by which trade leads to growth is mixed, and we do not know much about how it operates in low income countries.

The question is whether it is harder for an economy that receives a sustained increase in aid and so has a higher ratio of non-tradables to tradables to achieve the benefits of openness to the global economy. This is an important and somewhat neglected step in the argument of those who are concerned about the impact of Dutch Disease on growth.

An increase in aid will increase imports and reduce the relative size of the tradable sector - possibly leading to a lower level of exports in the short term. Trade - defined as imports and exports - will be likely to increase. The increase in imports will tend to have positive effects on productivity and growth; the reduction in exports will tend to have adverse effects. It is not clear which effect will dominate, and the net impact on economic growth of these offsetting effects from aid may well be quite small.

None of this implies any disagreement with the prevailing wisdom that openness to trade and export-led growth play a vital role in the development process. The point is to resist a simplistic analogy between the significant harm that can be done by policies which restrict openness and restrain the growth of trade, and the consequences of a one-off contraction of tradables caused by Dutch Disease. In contrast to broader restrictions on a country's ability to export, the Dutch Disease effect is accompanied by an increase in the country's capacity to import, from which many of the benefits of openness are likely to come; and it is a short-term contraction in tradable output, not a barrier to its future growth.

\section{Can aid be used to increase productivity?}

Yes. Thus far, we have looked only at the demand impact of the aid which leads to changes in the composition of domestic output. If the aid is used in ways that improve the supply side, and so help the country to export more or to improve its capacity to compete with imports, then the overall effect on output in general, including the tradable sector, may be positive.

Though aid is often described as if it is all used for investments which will enhance economic growth, a substantial proportion of aid is actually used to finance additional consumption. This is not a criticism of this sort of aid: increasing the consumption of very poor people is also a laudable policy objective in its own right. But this expenditure is less likely to increase productivity than aid used to finance investment.

A substantial proportion of aid is used in ways that is intended to increase productivity and growth. Some of this may have quite rapid effects on supply performance, such as investments in transport and communications infrastructure, improvements in power generation and distribution, fertilizer, irrigation and other agricultural technologies, or alleviation of administrative bottlenecks which make it difficult to do business. Other investments are intended to have effects over a longer time horizon. These include improvements in education, which may take a generation or more to feed into greater workforce productivity. Investments in health may increase productivity directly, and could have significant (possibly transformative) effects if they lead to increased life expectancy. ${ }^{18}$ Measures to improve the effectiveness of government institutions, reduce corruption, increase accountability, and improve the effectiveness of legal administration may increase growth and productivity in the long run by reducing

\footnotetext{
${ }^{18}$ Lorentzen, McMillan and Wacziarg, (2005).
} 
costs for business, reducing risk, enhancing property rights, creating a more stable investment climate and reducing the likelihood of conflict.

There are many empirical studies which find a positive impact of public infrastructure, education and health on productivity growth. ${ }^{19}$ The relationship between aid and increases in productivity is less clear, in part because there is no very clear relationship between higher public spending on services such as health and education and improvements in those services. However, a comprehensive analysis looking specifically at aid that is intended to promote economic growth in the short term shows that there is a robust positive correlation between aid and a country's economic growth in the medium term. ${ }^{20}$ This suggests that, on average, aid does have a positive effect on productivity and growth, at least when it is targeted on those results.

\section{What is the likely total impact on long-term growth?}

To the extent that aid is used in ways that increases productivity in both the tradable and non-tradable sectors, these improvements may at least offset any adverse effects of the appreciation of the real exchange rate.

Model simulations suggest that rather modest productivity benefits from aid would be sufficient to offset the possible dynamic costs of export contraction resulting from Dutch Disease. ${ }^{21}$

\section{What is the impact on total consumption and investment?}

In the long run, the citizens of a country that does not receive aid can only consume and invest as much as they produce between them. A current account deficit enables a country to consume more than it produces by borrowing from abroad temporarily, but in the long run the value of the country's output determines how much investment and consumption the country can afford. By contrast, if a country receives aid, it is able to sustain a higher level of investment and consumption than its output. ${ }^{22}$

The welfare of citizens increased by higher levels of consumption - and this is determined not only by what they produce themselves, but also by the additional consumption and investment that the aid finances. In other words when we consider the impact of aid on the welfare of its citizens, a possible adverse impact on output is not a sufficient reason to think that the aid may do more harm than good. What matters for total welfare is the combined effect of a possible reduction in output with the increases in consumption and investment that the aid permits.

The point can be illustrated with some representative figures. Suppose that aid to a developing country is increased substantially, by $20 \%$ of GDP. Suppose - pessimistically - that the aid has no beneficial impact on productivity, and that there is a large fall in exports - say a quarter - as a result of Dutch disease. If exports make up a fifth of the economy's output, this would mean that exports would fall by

\footnotetext{
${ }^{19}$ Calderon \& Servon (2003); Barro \& Sala-I-Martin (1995); Krueger \& Lindahl (2004).

${ }^{20}$ Clemens, Radelet and Bhavnani (2004). As with studies comparing aid with export performance, these correlations are suggestive rather than conclusive.

${ }^{21}$ See Adam (2005) and Adam \& Bevan (2004) for model simulations illustrating this dynamic benefit. These simulations suggest that exports might fully recover in 5-10 years.

${ }^{22}$ One way to think of this is that the aid finances a current account deficit.
} 
$5 \%$ of GDP. In practice, some or all of this fall in exports would be offset by a rise in tradable output and by the supply-side benefits of aid. But even if it were not, the fall in consumption and investment as a result of the significant fall in output resulting from Dutch disease (5\% of GDP) would be just a quarter of the value of the aid (20\% of GDP). Even in this worst-case scenario, the net effect of the aid on consumption and investment would be an increase of $15 \%$ of GDP.

It is clear that even under pessimistic assumptions about Dutch disease, with a large fall in tradables, no increase in non-tradable production and no productivity benefits from aid, overall consumption and investment would still be higher as a result of aid. It is highly implausible that the adverse effects of Dutch disease could be larger than the beneficial effects on average welfare of a sustained increase in aid.

Should we care about the impact on the real exchange rate?

Several studies have found that medium term economic growth can be accelerated by a depreciation of the real exchange rate. ${ }^{23}$ Almost all cases of sustained growth in sub-Saharan Africa have avoided overvaluation of the exchange rate. ${ }^{24}$ This suggests that an overvalued exchange rate would be a cause for concern if it has an adverse impact on growth. But there is little evidence that increases in aid are in fact correlated with an overvaluation of the exchange rate. ${ }^{25}$

In the normal course of a country's economic development, productivity and incomes increase. This leads to an appreciation of the real exchange rate over time. ${ }^{26}$ A rising real exchange rate is consistent with higher levels of domestic expenditure on non-tradables. Aid allows a higher level of consumption and investment than is justified by the productivity and output of the economy.

Just as there is no reason to worry that consumption and investment financed by aid become "too high" relative to economic output, it is not a cause for concern that the real exchange rate is "too high" relative to productivity. This real exchange rate is the result of the pattern of consumption and investment, including that financed by aid. Eventually, as the economy grows as productivity increases, aid will be replaced by exports and private capital flows to finance imports. The aid is intended to allow the economy to enjoy the benefits of higher productivity in advance of actually achieving it, and the appreciation of the real exchange rate is a corollary of the patterns of consumption and investment that the aid is intended to allow.

\section{What are the distributional effects of the Dutch Disease effect?}

Whether output falls or increases as a result of aid, in either the short run or the long run, there will be winners and losers as the composition of the economy changes. The appreciation of the real exchange rate that accompanies aid (and economic development) benefits net producers of non-tradables at the expense of net producers of tradables. The producers of tradables face an adverse change in their terms of trade (that is, revenues from their sales can buy less locally).

\footnotetext{
${ }^{23}$ Hausmann, Pritchett and Rodrik (2004).

${ }^{24}$ Surveyed in Gupta, Powell \& Yang (2005).

${ }^{25}$ Surveyed in Adam (2005).

${ }^{26}$ The Balassa-Samuelson hypothesis is that because the traded goods sector has higher productivity growth than the nontraded goods sector, the real exchange rate appreciates as income grows.
} 
This appreciation of the real exchange rate will have a negative impact on rural households producing cash crops for export. By contrast, rural household that produce non-tradable food crops, which are generally the majority, are likely to see a rise in incomes. ${ }^{27}$

The suppliers of goods and services to government, who tend to live in towns and cities, may gain even more than non-tradable food producers. If the aid is used successfully to improve competitiveness, then the export sector will benefit as well.

Overall, the incomes of the poorest are likely to rise, but it is not clear whether they will rise more or less than the incomes of other citizens. This depends on the structure of the economy, and how the aid is used.

\section{What if the aid increase is not sustained?}

We have seen that the impact of a sustained increase in aid is to cause a shift of productive resources from tradables to non-tradables. The direct effect is to reduce the size of the tradable sector, which can be offset or even reversed if the aid is used in ways which increase short-run and long-run productivity. If the aid is sustained while productivity rises and the economy grows, the role of aid in financing imports can eventually be replaced by higher exports and private capital flows.

If a country receives a short-term increase in aid, however, the calculation looks rather different. If the country absorbs and uses the aid rather than saves it, then at least some of the benefit will take the form of an appreciation of the real exchange rate and a reduction in the relative size of the tradable sector. ${ }^{28}$ Once the aid stops, then the structure of output has to shift back, leading to an increase in tradable production at the expense of non-tradables. Both these changes involve transitional costs including job losses, training, bankruptcies, internal migration, and the administrative costs of establishing and closing businesses.

A temporary disruption in the competitiveness of an export firm may have devastating consequence for its long-term profitability, especially if it does not have access to financial markets that enables it to smooth out the effect of temporary shocks. As local prices rise, firms either have to put up their prices and lose customers, or continue to sell at a loss, and face bankruptcy and closure. When the exchange rate spike has passed, the country has fewer firms, and a smaller share of export markets, from which it may take years to recover.

The total benefits of a temporary increase in aid which may well not be sufficiently large to compensate for the macroeconomic instability and transitional costs that it causes.

\section{How can countries cope with a temporary increase in aid?}

Because of the costs of the macroeconomic effects of a temporary increase in aid described above, recipient countries have to be very careful about how they use short term changes in aid. ${ }^{29}$

If aid is received which is likely not to be sustained, they can:

\footnotetext{
${ }^{27}$ Adam (2005).

${ }^{28}$ Technically called "absorbing" the aid. Note that "absorption" is used in at least three different ways in the aid literature.

${ }^{29}$ The technical issues surrounding these choices are discussed in detail in Gupta, Powell \& Yang (2005).
} 
* Use the aid to build up foreign exchange reserves. This means that the aid is not used immediately, but the benefits are spread over time.

* Use the aid for an import which (a) the country would not have imported otherwise and (b) does not substitute for locally produced goods. An example might be to use aid to buy vaccines for a measles immunization campaign.

* Spend the aid in ways that has unambiguously large, short term benefits to productivity of exporters - for example, dredging the port or improving the power generation capacity.

How should donors respond to the possibility of Dutch Disease?

Donors should take account of the macroeconomic disruption that increased aid can cause, in the following ways:

* Aid should be more stable. ${ }^{30}$ Aid that varies significantly can lead to more economic costs than benefits.

* Aid should be more predictable. This enables the recipient government to manage the macroeconomic effects of total aid flows, through monetary and fiscal policy.

* Recipient governments should be given discretion to use aid flexibly, including by saving it in the form of foreign exchange reserves. Donors should not use "additionality" rules and other mechanisms to limit the recipients' choices.

It is important to direct some aid towards activities that will enhance long-term economic productivity.

* Dutch disease should not be represented as a limitation the amount of sustained aid that can be given to developing countries. Any reduction in output because of an appreciation of the real exchange rate is more than offset by the additional consumption and investment that the aid finances.

Owen Barder

Center for Global Development

July, 2006

\footnotetext{
${ }^{30}$ Bulir \& Hamann (2001) assessed the volatility of aid compared with domestic revenues, and found that on certain measures (in US\$ as \% of GDP), aid is four times as volatile as domestic revenues; and for highly aid dependent countries, aid is seven times more volatile than domestic revenue. Furthermore, in 2005 they found that aid volatility may be getting worse over time.
} 


\section{References \& further reading}

Adam, Christopher, (2004). "Fiscal Policy Design in Low-Income Countries," in Fiscal Policy for Development: Poverty, Reconstruction, and Growth, ed. by Tony Addison and Alan Roe (New York: Palgrave MacMillan). http://www.economics.ox.ac.uk/Members/david.bevan/Papers/AdamBevan_revised.pdf

Adam, Christopher, (2005). "Exogenous Inflows and Real Exchange Rates: Theoretical Quirk or Empirical Reality?" paper presented at IMF Seminar on Foreign Aid and Macroeconomic Management, Maputo, Mozambique, March 14-15. http://www.economics.ox.ac.uk/Members/christopher.adam/Own_pdfs/Adam_FAMM_Revised_Sept 2 $\underline{005 . p d f}$

Adam, Christopher, and David Bevan, (2003). “Aid, Public Expenditure and Dutch Disease," CSAE Working Paper 184 (Oxford: Centre for the Study of African Economies, Oxford University). http://www.bepress.com/csae/paper184

Adam, Christopher, and David Bevan (2004). "Aid and the Supply Side: Public Investment, Export Performance and Dutch Disease in Low Income Countries," Department of Economics Discussion Paper Series 201 (Oxford: Department of Economics, Oxford University). http://www.economics.ox.ac.uk/Research/wp/pdf/paper201.pdf

Adam, Christopher, David Bevan, and Gerard Chambas, (2001). "Exchange Rate Regimes and Revenue Performance in Sub-Saharan Africa," Journal of Development Economics, Vol. 64. http://ideas.repec.org/p/oxf/wpaper/009.html

Adenauer, Isabell, and Laurence Vagassky (1998). "Aid and the Real Exchange Rate: Dutch Disease Effects in African Countries," Intereconomics, Vol. 33, No. 4, pp. 177-85.

Andrews, David, Lodewyk Erasmus, and Robert Powell (2005). "Ethiopia: Scaling Up" Finance and Development, Vol. 42, No. 3 (September), pp. 32-35. http://www.imf.org/external/pubs/ft/fandd/2005/09/andrews.htm

Barder, Owen (2006), “Are the planned increases in aid too much of a good thing?”, Center for Global Development Working Paper \#90, Washington, D.C. July 2006.

Barro, Robert \& Sala-I-Martin, Xavier. (1995), “Economic Growth”. New York: McGraw-Hill. (1995).

Berg, Andrew \& Anne O. Krueger, "Trade, Growth, and Poverty: A Selective Survey" (February 2003). IMF Working Paper No. 03/30. http://ssrn.com/abstract $=879105$

Bevan, David (2005). "An analytical overview of aid absorption: Recognizing and avoiding macroeconomic hazards". Paper for the Seminar on 'Foreign Aid and Macroeconomic Management', March 14-15, Maputo, Mozambique. In Peter Isard, Leslie Lipschitz, Alexandros Mourmouras, and Peter Heller (eds). Macroeconomic Management of Foreign Aid: Opportunities and Pitfalls. Forthcoming, International Monetary Fund, Washington, DC. http://www.imf.org/external/np/seminars/eng/2005/famm/pdf/bevan.pdf

Bourguignon, François and Mark Sundberg (2006). Constraints to Achieving the MDGs with Scaled-Up Aid. DESA Working Paper No. 15 http://www.un.org/esa/desa/papers/2006/wp15 2006.pdf

Brautigam, Deborah, and Stephen Knack (2004). "Foreign aid, institutions and governance in Sub-Saharan Africa." Economic Development and Cultural Change 52 (2): 255-286. http://www.journals.uchicago.edu/EDCC/journal/issues/v52n2/520201/520201.web.pdf 
Bulír, Aleš, and Timothy Lane, (2002). “Aid and Fiscal Management,” IMF Working Paper 02/112 (Washington: International Monetary Fund). http://www.imf.org/external/np/res/seminars/2002/poverty/abtl.pdf

Bulír, Aleš, and A. Javier Hamann (2003). “Aid volatility: An empirical assessment” IMF Staff Papers 50 (1): 64-89. http://ideas.repec.org/a/imf/imfstp/v50y2003i1p4.html

Buliř, Aleš, and A. Javier Hamann (2005). Volatility of development aid: from the frying pan into the fire? International Monetary Fund paper presented at the Seminar on Foreign Aid and Macroeconomic Management, Maputo, 14 and 15 March. http://www.imf.org/external/np/seminars/eng/2005/famm/pdf/hamann.pdf

Burnside, Craig, and David Dollar (2000). “Aid, policies and growth" American Economic Review 90 (4): 847868. http://www.worldbank.org/html/dec/Publications/Workpapers/WPS1700series/wps1777/wps1777.pdf

Burnside, Craig, and David Dollar (2004). "Aid, policies and growth: Revisiting the evidence" Policy Research Working Paper No. 3251, World Bank, Washington, DC. http://ideas.repec.org/p/wbk/wbrwps/3251.html

Calderon, Cesar \& Serven, Luis (2003), "The Effects of Infrastructure Development on Growth and Income Distribution", World Bank Policy Research Working Paper, No 3400. http://ideas.repec.org/p/wbk/wbrwps/3400.html

Chowdhury, Anis and Terry McKinley (2006). "Gearing macroeconomic polices to manage large inflows of ODA: The implications for HIV/AIDS programmes" UNDP International Poverty Centre, Working Paper \# 17. May 2006. http://www.undp-povertycentre.org/newsletters/WorkingPaper17.pdf

Clemens, Michael A., Steven Radelet and Rikhil Bhavnani (2004). "Counting chickens when they hatch: The short term effect of aid on growth." Working Paper No. 44, November, Center for Global Development, Washington, DC. http://www.cgdev.org/content/publications/detail/2744

Easterly, William, Ross Levine, and David Roodman (2003). "New data, new doubts: A comment on Burnside and Dollar's 'Aid, policies, and growth"” CGD Working Paper No. 26. Centre for Global Development: Washington DC. Published as 'Aid, Policies, and Growth: Comment', American Economic Review, 94 (3): 774-780.

http://www.cgdev.org/content/publications/detail/2764

Ghei, Nita, and Lant Pritchett, (1999). "The Three Pessimisms: Real Exchange Rates and Trade Flows in Developing Countries," in Exchange Rate Misalignment: Concepts and Measurement for Developing Countries, by Hinkle and Montiel (Washington: OUP/World Bank).

Gupta, Sanjeev, Yongzheng Yang \& Robert Powell (2005). “The Macroeconomic Challenges of Scaling Up Aid to Africa." IMF Working Papers. http://ww.imf.org/external/pubs/ft/wp/2005/wp05179.pdf

Gupta, Sanjeev, Benedict Clements, Alexander Pivovarsky, and Erwin R. Tiongson (2003). "Foreign Aid and Revenue Response: Does the Composition of Aid Matter?” IMF Working Paper WP/03/176. International Monetary Fund, Washington, D.C. http://www.wider.unu.edu/conference/conference-2003-3/conference-2003-3-papers/Gupta-clementspivovarsky-tiongson-0808.pdf

Harms, P., and M. Lutz (2005). “The Macroeconomic Effects of Foreign Aid.” In: H. Ahrens (ed.), Development Cooperation - Evaluation and New Approaches. Berlin: Duncker \& Humblot. 
http://www.vwa.unisg.ch/org/vwa/web.nsf/SysWebRessources/VWA_2004_11/\$FILE/dp11_harmslutz_ganz.pdf

Hausmann, Ricardo, Lant Pritchett, and Dani Rodrik, 2004, “Growth Accelerations," NBER Working Paper 10566 (Cambridge, Massachusetts: National Bureau of Economic Research). http://papers.ssrn.com/sol3/papers.cfm?abstract id=571823

Heller, Peter S. (2005). Pity the finance minister: Managing a substantial scaling-up of aid flows. Fiscal Affairs Department, International Monetary Fund, Washington, DC. http://www.imf.org/external/pubs/ft/wp/2005/wp05180.pdf

Heller, Peter S., and Sanjeev Gupta (2002). "Challenges in expanding development assistance." IMF Discussion Paper PDP/02/5, March, International Monetary Fund, Washington, DC. http://www.imf.org/external/pubs/ft/fandd/2002/06/heller.htm

International Monetary Fund (2005a). "The macroeconomics of managing increased aid inflows: Experiences of low-income countries and policy implications." August 2005, Policy Development and Review Department, International Monetary Fund, Washington, DC. http://www.imf.org/external/np/pp/eng/2005/080805a.htm

International Monetary Fund, (2005b), "Monetary and Fiscal Policy Design Issues in Low Income Countries" (unpublished; Washington: International Monetary Fund). http://www.imf.org/external/np/pp/eng/2005/080805m.htm

Kraay, Aart (2005). “Aid, growth, and poverty” In Peter Isard, Leslie Lipschitz, Alexandros Mourmouras, and Peter Heller (eds). Macroeconomic Management of Foreign Aid: Opportunities and Pitfalls. Forthcoming. International Monetary Fund, Washington, DC. http://www.imf.org/external/np/seminars/eng/2005/famm/pdf/kraay.pdf

Kraay, Aart, and Claudio Raddatz (2005). "Poverty traps, aid and growth" World Bank Policy Research Working Paper No. 3631, June, World Bank, Washington, DC. http://siteresources.worldbank.org/INTMACRO/Resources/KraayRaddatzPovertyTrapsApril2005.pdf

Krueger, Anne \& Lindahl, Mikael. (2004), “Education for Growth: Why and for Whom?”, Journal of Economic Literature, 39 (Dec 2004), pp1101-36.

Krugman, Paul (1987). "The Narrow Moving Band, the Dutch Disease, and the Competitive Consequences of Mrs Thatcher: Notes on trade in the presence of dynamic scale economies", Journal of Development Economics 27 (1-2), 41-55.

Lawrence, Robert Z. and David E. Weinstein (1999). "Trade and Growth: Import-Led or Export-Led. Evidence from Japan and Korea”. NBER Working Paper No. 7264, July 1999. http://www.nber.org/papers/w7264.pdf

Lorentzen, Peter L., John McMillan, and Romain T Wacziarg, (2005), "Death and Development" (September 2005). NBER Working Paper No. W11620 http://ssrn.com/abstract $=807609$

McKinely, Terry (2005). "Why is 'the Dutch Disease' always a disease? The macroeconomic consequences of scaling up ODA". International Poverty Centre Working Paper 10, UNDP, New York. November 2005. http://www.undp-povertycentre.org/newsletters/WorkingPaper10.pdf

Nkusu, Mwanza, (2004). "Aid and the Dutch Disease in Low-Income Countries: Informed Diagnoses for Prudent Prognoses,” IMF Working Paper 04/49 (Washington: International Monetary Fund). http://ideas.repec.org/p/imf/imfwpa/04-49.html 
Nyoni, Timothy S., 1998, "Foreign Aid and Economic Performance in Tanzania," World Development, Vol. 26, No. 7, pp. 1235-40. http://dx.doi.org/10.1016/S0305-750X(98)00047-3

Prati, Alessandro, Ratna Sahay \& Thierry Tressel (2003). "Is there a Case for Sterilizing Foreign Aid?" mimeo (European Economic Association, Stockholm, August). http://www.imf.org/external/np/res/seminars/2003/lic/pdf/tt.pdf

Rajan, Raghuram, and Arvind Subramanian (2005a). “What undermines aid's impact on growth?” IMF Working Paper WP/05/126, June, International Monetary Fund, Washington, DC. http://www.imf.org/external/pubs/ft/wp/2005/wp05126.pdf

Rajan, Raghuram, and Arvind Subramanian (2005b). "Aid and growth: What does the cross-country evidence really show?” IMF Working Paper WP/05/127, June, International Monetary Fund, Washington, DC. http://www.imf.org/external/pubs/ft/wp/2005/wp05127.pdf

Rodrik, Dani. (1999). The New Global Economy and Developing Countries: Making Openness Work. Washington, D.C.: Overseas Development Council.

Sackey, Harry A., (2002). "External Aid Flows and the Real Exchange Rate in Ghana," AERC Research Paper 110 (Nairobi: African Economic Research Consortium). http://www.aercafrica.org/documents/rp110.pdf

Sala-i-Martin, Xavier \& Arvind Subramanian, Addressing the Natural Resource Curse: An illustration from Nigeria. Working Paper WP/03/139 (International Monetary Fund, Washington, DC, 2003) http://papers.ssrn.com/sol3/papers.cfm?abstract id=420318

Sundberg, Mark, and Hans Lofgren (2005). Absorptive capacity and achieving the MDGs: The case of Ethiopia. In Peter Isard, Leslie Lipschitz, Alexandros Mourmouras, and Peter Heller (eds). Macroeconomic Management of Foreign Aid: Opportunities and Pitfalls. Forthcoming, International Monetary Fund, Washington, DC. http://www.imf.org/external/np/seminars/eng/2005/famm/pdf/sundbe.pdf

Tornell, Aaron, Frank Westermann \& Lorenza Martinez, (2004). "NAFTA and Mexico's Less-Than-Stellar Performance”, NBER Working Papers 10289, National Bureau of Economic Research, Inc. http://ideas.repec.org/p/nbr/nberwo/10289.html

World Bank (1993). The East Asian Mirale. New York, Oxford University Press. 